\title{
BIBLIOTECAS OU CENTROS DE CULTURA?
}

\author{
Justino Alves Lima
}

MILANESI, Luiz Augusto. A casa da invenção: biblioteca, centro de cultura. 3.ed. rev. e amp. São Paulo: Ateliê Editorial, 1997. 271p.

Bibliotecas ou centros de cultura? Os dois. É a proposta apresentada por Milanesi em "A casa da invenção: biblioteca, centro de cultura".

Os versos poéticos de Vinicius (era uma casa muito engraçada/ não tinha parede/ não tinha nada) encontra um paralelo na casa da invenção trabalhada por Milanesi. Secularmente tradicional, a instituição biblioteca também carrega o símbolo de secularmente abandonada. No entanto, a biblioteca ideal transita no imaginário desse bibliotecário que faz do seu sonho um exercício prático. Tem sido assim, seja quando da construção do Sistema de Bibliotecas Públicas do Estado de São Paulo, seja quando produz os seus textos. A casa da invenção é isso, um livro graficamente perfeito, extremamente bem elaborado, sendo coerente com a proposta de construção de uma casa arquitetonicamente bem desenhada e engenhosamente bem construída.

Lamentável, apenas, que essa construção (A casa da invenção) não seja uma realidade brasileira. Quando muito, sonhos que se concretizaram em espaços isolados. O autor trabalha sempre com a idéia de cidades pequenas para provar/provocar os seus sonhos.

O autor compara uma biblioteca tradicional com uma contemporânea e faz uma análise da informação que circula num centro cultural onde

a biblioteca torna-se imprescindível. A integração entre oficinas de arte, ministração de cursos e a biblioteca significa a articulação das partes que justificam a conjugação dos verbos informar, discutir e criar. Registra-se aqui um dos pontos altos do livro (capítulo 10, o texto "Três verbos"), onde informar, discutir e criar transmudam-se em recuperação, potencialização e permanência de informação no coletivo de usuários dos centros de cultura.

Outro grande momento do livro é o texto "Lili e os moinhos", no capítulo nove, algo para ser lido e digerido tal qual "Os filhos da Candinha" de Mário de Andrade.

Com o tempo perdeu-se o conceito de biblioteca tradicional, do modelo quinhentista da coleção de livros, e incorporaram-se atividades menos convencionais como palestras, exposições, debates, encenações e outras afins. Então a biblioteca passou a ter atividades culturais, avançando do seu conceito tradicional para o moderno de centro de cultura, ou faz parte de um deles. O texto de Milanesi então contempla os dois, biblioteca e centro de cultura, o que termina por fortalecer a primeira.

Milanesi trabalha contra a existência de duas redes (biblioteca para um lado e centro de cultura para outro) e advoga a tese de que o mais racional é, "a partir das bibliotecas existentes, 
investir na correção de rota, na sua dinamização e ampliação". Essa correção de rota corrigiria historicamente o processo evolutivo das mesmas, que inexplicavemente (seria mesmo inexplicável?) tiveram seus desenvolvimentos interrompidos. E a dinamização, "incorporando as exigências do tempo, só poderá apontar para espaços polivalentes que respondem com mais eficiência à necessidade de instituir ações alternativas de acesso ao conhecimento e à criação de novos".

A aposta do autor na existência irmanada das duas instituições reside na convicção de que a biblioteca deixou de ser uma coleção de livros e o centro não pode existir sem informações disponíveis. Configura-se, assim, um espaço polivalente onde o cidadão convive com a possibilidade de pensar e de se expressar. O nome, se biblioteca ou centro de cultura, o tempo definirá.

\section{Justino Alves Lima}

Bibliotecário da Universidade Federal de Sergipe. 